\title{
LEGAL PROTECTION OF THE DEBTOR CONSTRUCTION COMPLETION OF NON- PERFORMING LOANS BY AUCTION OF LIABILITY WARRANTIES
}

\author{
Lusia Sulastri \\ University of Gunungjati Cirebon
}

\begin{abstract}
The resolutions of non-performing loans with tendering guarantee Encumbrance Often bring up the resistance of the debtor in the form of Civil Lawsuit filed to the District Court the which is due to the complexity of the auction and Several weaknesses inherent in the Mortgage Law. Issues that will be Examined is the debtor regarding the cause of the resistance and constructing legal protection for the debtor, the which will then be Analyzed by Juridical reasons debtor resistance and constructing legal protection for debtors. Resistance debtor raises the conception of the construction of legal protection to the debtor will be maintained, as well as the Law on Consumer Protection the which regulates legal protection for debtors and Also Provides protection against collateral in the debtor from the arbitrariness of the determination of the limit value by "tendering Crime" in the tendering process the security object security rights. Weakness contained in UUHT and determination of limit values of objects in the tendering process encumbrance Become the subject matter of this study. For it is very important that creditors be cautious in making loans to its customers, in the handling of non-performing loans,
\end{abstract}

Keywords: Non Performing Loans; Tendering Process of Mortgage (Right Insurance / Mortgage) Collateral; Debtor Legal Protection; Banking Law; Civil Law.

\section{A. INTRODUCTION}

Business dynamics with the ebb and flow has resulted to the survival of a contractual relationship, as in this case the author highlights the contract / agreement banking; what is projected smoothly, fortunately, satisfactory, but what power expected business prospects bright sometimes can turn losers and disconnected the parties to a contract. The contracting parties always hoped his contract expires with the 'happy ending' but in fact there is the possibility of a contract obstacles even lead to the failure of contracts that give rise to disputes and conflicts on the side.

In a credit, the bank or the provider always hoped that the debtor may discharge its obligation to repay on time to credit has been received. In practice, not all the credit that has been issued by a bank run and ended smoothly. Not a few credit crunch caused by the debtor can not repay the loan on time as agreed in the loan agreement between the debtor and the banking firm. Things that cause a credit crunch for example because the debtor is unable or because of deterioration of business and the failure of which result in reduced revenues of the debtor or the debtor intentionally did not want to pay because the debtor is not good character.

Based on the state of the debtor so, then the creditor seeks to take a settlement of accounts receivable with asset sales collateral debtors so was born the Act Encumbrance (UUHT) designed to provide 
legal certainty as the right of a strong guarantee, with the typical execution "easy and sure" but it turns out in Pratiknya not. The process of settlement of non-performing loans by auction guarantee security rights often led to opposition from the debtors (customers) in the form of a civil suit filed to the District Court.

Research into civil lawsuit No. 09 / Pdt.G / 2013 / PN.Mjl, No. 81 / Pdt.G / 2013 / PN.Cbn, and No. 10 / Pdt.G / 2014 / PN.Mjl aims to analyze the weaknesses that exist in the Mortgage Law in particular Article 6 and Article 20 were used as an opportunity to lodge opposition by the debtor. Such articles seem vague and not firmly set on the definition of injury Promise (defaults) a debtor, limit the authority to sell the object Encumbrance that cause confusion, as well as the complexity of the auction are mainly related to the determination of the limit value objects auction unilaterally by the lender assessed not reasonable.

In addition to the creditors (banks) own indecision Mortgage Law has a negative impact on the efficiency aspects of economic actors for the process of problem loans and settlement procedures with the auction takes too long and complicated and the cost is very high.

The phenomenon of resistance debtor indicates that law enforcement execution of the security rights is one of the dark side of law enforcement in Indonesia. This is the rationale for the author to do more research regarding the applicability of Law Encumbrance by stressing the completion of non-performing loans with mortgages auction relevanced Debtor in Case Resistance against the auction of mortgage in the District Court of Majalengka and Cirebon District Court.
In this study discusses the causes of settlement of non-performing loans with collateral Mortgage auction if met with resistance from the debtor. In addition, this study also seeks to create a debtor legal protection construction in the settlement of problem loans with collateral Mortgage auction.

\section{B. DISCUSSION}

\section{Reason Juridical Debtor Resistance against NPL Settlement With Mortgage \\ Implementation Auctions Guarantee}

Opportunities Debtor resistance to the process of settlement of nonperforming loans by auction jaminana Encumbrance very large as the Law on Mortgage (UUHT) does not regulate the definition of default, it is to determine whether the debtor injury promise in determining compliance with Article 6 UUHT referred to in Article 1243 jo, Article 1763 of the Civil Code: In the provisions of Article 1243 of the Civil Code, the definition of injury or tort promise:

a. Failure to fulfill the agreement, or

b. Do not submit or pay within the specified time period, or

c. Do not do as promised within the time limit prescribed.

More specifically Article 1763 of the Civil Code says, does not return the loan according to the loan amount within the specified time period. For comparison, in some countries regulated in more detail when the debtor is called the injury a promise or default. Violating any of the provisions of the agreement relating to the loan principal and / or interest (interest), which does not pay interest on at least two (2) months. The offense has been notified to the debtor, but even 
though it was past three (3) months, have gone unheeded. In circumstances like these are categorized debtor had been in breach of some covenants in the mortgage deed.

In addition Article 1267 of the Civil Code gives the option to the creditor to take action if the debtor defaults, regardless of whether the agreement was due or not in the form of a request or demand conditions for the court to compel the debtor meets the agreement, if it can still be done by the debtor. Demanding cancellation of the agreement along with reimbursement of losses and interest. In connection with the explanation regarding the tempo jantuh credit, can not be approved or not proper opinion of the Supreme Court in its Decision No. 2/72 K / Pdt / 1992 dated May 29, 1998 which states:

Because the High Court of Aceh I Judex facti misapplied the law, assessing the maturity of the loan repayment and the "Joint Statement" that is required by the provisions of Article 10 of Act No. 49 Government Regulation of 1960 with only based on the length of the loan is not paid by the Cassation / compa / Pelawan without considering the grace period, ie the due repayment guarantee.

The above consideration is less clear formulations but may be a justification on grounds the appeal filed Cassation, that in this case the case has not occurred because of bad credit loan repayment term limits have not yet matured, for an agreed maturity is December 1992. Thus Bank through PUPN not been able to execute an auction sale of the assets of the debtor.
Can be seen, in the case of this execution, the Supreme Court found the execution of HT or assets of the debtor through PUPN unenforceable by reason of default, as long as the credit limit repayment period agreed upon are not yet due. Opinion of the Supreme Court which took over the District Court judgment in this case is very dangerous in traffic credit. For example, Ioan repayment maturity of the contracted 10 years, but only the first year has been broken a debtor to pay the principal and interest. In this case if the opinion of the Supreme Court followed its application, means a new creditor or bank can demand payment after a period of 10 years passed.

Such opinion and the application, the terms provide flexibility to borrowers mistreatment. On the contrary opinion as a party that puts creditors are vulnerable to abuses on purpose.

In connection with that, in the case of more precise and more based on the opinion of the High Court in appeal. According to the High Court (excerpted as follows):

- It has been proven credit has been stalled by the fact that Pelawan / debtors have for years do not pay the loan installments of principal and interest, and things according to Article 3 (3) of the Regulation of the Minister of Finance No. 2 / PMK 01/1997, including investment credit loans are jammed;

- In addition, Article 6 (3) confirms, Bank / creditor can declare immediately due credit if the debtor defaults and loan classified as loss, by the exclusion of maturity specified in the agreement; 
- Letter regarding the Joint the statement between debtors with PUPN, under Article 10 of Government Regulation No. 49 of 1960, could not be held on the grounds:

a. Contrarian / debtors have 4 times called PUPN, but still present sodium absorption ratio;

b. In such a case, under Article 11 of Government Regulation No. 49 of 1960, PUPN can immediately issuing country Forced for collect receivables from debtors;

c. Thus, execution of confiscation and auction sales that have been made PUPN and Auction Office in case this case is lawful.

Judgment and opinion of the High Court in the above, in addition to rational and objective, also based on the legislation that is strong and accompanied by a proper understanding of the definition of default set out Article 1243 and Article 1763 of the Civil Code. Therefore, that is worth following is the opinion of the High Court, not the Supreme Court's opinion.

The concept of Constituent Mortgage initially is to provide convenience to the creditor, so that the lender can recover his money in a way easier and cheaper, then Article 6 UUHT which ex lege could also strengthen the position of creditors when debtors of default, by giving provisions that can be used in the form of rights to sell on its own power over the object in order to take repayment of the loan guarantee. For more details UUHT in Article 6, states:
"If the debtor in default, Mortgage Holder has the right to sell the object of Encumbrance on its own power through a public auction and take the settlement of receivables from the sale proceeds. "It

Understanding of the article can be said that there was absolutely right to sell on its own power is no longer foretell through kuasan or implementation is not based on the power again, for giving parate execution by law (ex lege), with the aim of sake and to strengthen the position of creditors holders Mortgage and parties get the right of him.

Article 6 expressly UUHT provide an understanding that the authority to sell on its own power is given to the holder of the first Mortgage, although there are no promises contained in the Deed of Encumbrances Encumbrance, known as van eigenmatig Verkoop beding. It shows the union of an authority that was originally born out of an agreement (promise) become a norm that binds, as provided by law (ex Legie), it is a peekembangan which leads to an improvement compared to the provisions of Article 1178 (2) BW entry into force of mortgages.

However, when reading the explanation of Article 6 UUHT then linked with Article 6 UUHT would create confusion, because the explanation this article provides that:

"The rights, namely the right to sell the object of Encumbrance on its own power is one preferred embodiment of the position that

1 Poesoko Herowati, 2007, Parate Executie Obyek Hak Tanggungan (Inkonsistensi, Konflik Norma dan Kesesatan Penalaran dalam UUHT), LaksBang Pressindo, Yogyakarta, P. 249 
belongs to the holder or holders Mortgage First Mortgage in case there is more than one (1) Holders of Mortgage. The rights are based On if the debtor injury Promise pledge, the holder is entitled to sell the Mortgage object Encumbrance through public auction without requiring further approval from lender Mortgage and subsequently took the redemption proceeds receivable from ahead of other creditors ... "."

According to the explanation of Article 6 UUHT at least gives two (2) understanding of, first, the right of creditors to sell the object of Encumbrance on its own power is based on the promise if the debtor injury appointment, and secondly, the right to sell the object of Encumbrance on its own power is one preferred embodiments of the position that belongs to the Mortgage Holder.

The right to sell on its own power, according to Article $6 \mathrm{UUHT}$ explanation is based on the promise. It is very different to Article 6 UUHT are on the right under the law (ex lege). The big difference in the meaning of the birth of creditors rights to sell the object of Encumbrance on its own power show UUHT formers who have attitudes that are inconsistent, leading to confusion and frustration for the creditors in particular, Article 6 UUHT so the explanation is actually again confront the banking expectations. Actually, the law only provides banking expectations, but it shows risky if one law (UUHT) regulate the same object, namely parate execution, but it gives a different meaning to each other. Differences are reflected in the meaning of Article 6
UUHT, that the right to sell on its own power is given by law (ex lege), but the authentic interpretation of forming UUHT as in the elucidation of Article 6, the right to sell on its own power, not meant to be ex lege but on the basis of agreed upon beforehand. This setting becomes excessive and would give rise to disagreement which unceasingly, that can be said to occur inconsistent in its regulation.

Basically the arrangement regulations that full consistency can not be separated from his relationship with systematic legal regulations the others, because the law is a system means that means that is a unified whole consisting of parts or elements that are related to each another, or in other words, the legal system is a unit consisting of the elements that have interactions with each other and work together to achieve this unity. Unity is applied to complex juridical elements, such as the rule of law, principles of law and the legal sense. Arrangements are inconsistent against the rights of creditors are set out in Article 6 UUHT with Explanations in Article 6, then for the sake and for legal protection and legal certainty for the creditors,

Based on Presidential Decree No. 44 of 1999 on the Drafting of Legislation and Forms of the Bill, the Draft Regulation and Draft Presidential Decree dated May 19, 1999, the State Gazette of the Republic of Indonesia of 1999 No. 70, on the second, on Matters Special, II A, The explanation stated: ${ }^{3}$

"Basically the formulation of the explanation of legislation can not be used as a backrest for the subject matter set forth in 
the torso. Therefore, the preparation of the formulation of norms in the torso should be clear and not cause doubts ",

If the above-mentioned regulations associated with the Article 6 UUHT explanation, the explanation of Article 6 UUHT can not be relied upon for the subject matter regulated in the body that is Article 6 UUHT. Explanation norm should not conflict with the content (substance) norms, and an explanation of the norm is not binding, because the explanation of a norm is not a norm. Explanation in respect of Article 6 UUHT not the norm when there is a dispute, then the position of the Explanation of Article 6 UUHT not have binding legal force. Therefore, by basing these reasons, it is clear Mortgage creditors rights holders first to sell the object Encumbrance is on the basis of law and not on the basis of the agreement.

Further in Penejelasan Article 6 UUHT, Shaping UUHT also has mencampuradukan parate executie with preferred creditor position. To examine this, the starting point of the type of rights contained in Act No. 4/1996. Actually Mortgage is a type of rights whose existence is born through agreements held by the parties. Warranty agreement Mortgage spawned it, made by the parties with the aim to complete the basic agreement that is generally in the form of agreement of debts or credit agreement. Under an agreement in respect of the guarantee provided by the debtor is land (immovable), means that the parties will make the guarantee agreement Mortgage. This agreement is qualified as material agreements, Mortgage born thus classified as kebendaaan (zakelijk). As it is known that the right material has characteristics very superior as no preference, droit de suit, priorities, and absolute. Due to continued, creditors or banks that have Encumbrance is classified as a preferred creditor, no longer as a creditor konkruen.

Although the legislation does not give an official explanation of what is meant by "position precedence", but rests of Article 1 (1) UUHT, but to remember the position of holders of mortgages in BW as a creditor preference, would be expected, that is with "preferred position" equal "position as a preferred creditor". For this there is need to know about "The position as a preferred creditor" means, guarantee creditors rights holder that they take precedence in making the repayment on the results of execution of certain objects insurer in relation to the Mortgage specifically diperikatkan to guarantee the creditors bill. Therefore,

If true intention of the legislator as mentioned above, the further provisions of Article 1 (1) UUHT connected with Article 20 (1b) UUHT, which is located in Chapter $\mathrm{V}$ of Execution Mortgage, which regulates: ${ }^{4}$

"... for the settlement of holders with the right to precede rather than other creditors ".

The word "right precedes" if connected with the events of "execution" of course, means "precedence" in taking over the repayment of proceeds from disposal of objects or objects that are pledged. Thus, the position of creditors Mortgage holders referred to as "preferred", while the implementation of the rights referred to "take precedence". That is the precedence of execution of 
the other creditors, although no further explanation is given by law, but presumably once again based on the experience of the mortgages may suspect that what is meant is the precedence of the creditors konkruen, as the rationale is Article 1132 in conjunction with Article 1138 BW

As a consequence of the position of holders of Mortgage preferred or mendahulu, then the object Mortgage can be loaded more than one Mortgage, so there is a holder of Mortgage ranked first, second and so on, so that by itself the holder of Mortgage older would have accrued to the higher than the next Mortgage holders. Mortgage holders are ranked by Article 5 UUHT. So that the creditor has a right to claim a position as a preferred creditor, the creditor position to be very strong. According Isnaeni, this pattern can be relied upon to support the business activities of the economic actors who always wanted efficiency. Creditors with the preferred position,

But it turns out when reading the explanation of Article 6 UUHT mentioning that, right to sell the object Encumbrance on its own power is one manifestation of the notch preferably owned by the holder of Mortgage or holders of Encumbrance first in case there is more than one holder Mortgage. ${ }^{5}$ An understanding of the explanation of Article 6 UUHT, turned out to legislators to confuse the right to sell the object of Encumbrance on its own power (parate executie) with a preferred embodiment of the position that belongs to Mortgage holders (preferred creditor).

According to J. Satrio, parate execution authority is not an embodiment of the position of creditors as a preferred

5 Ibid, P.256 creditor / preference, the right is an embodiment of one aspect of the position of creditors who appoint special security interest, or which by law is given special authority, namely provide convenience to creditors in making the repayment. The author agrees with J. Satrio, arguing that the rights to sell the object of Encumbrance on its own power is not a preferred embodiment of the position, but as the embodiment accelerate the repayment of receivable creditor principle, because parate executie an execution that deviates from the principles set out in the execution of the Civil Procedure Code,

To the confusion in the Explanation of Article 6 UUHT little more confusing holders of collateral, particularly for creditors holders of Mortgage first, because although basically the birth of parate executie be contracted and will be binding on the parties, but as a norm must be clear and unequivocal so as not to cause an understanding doubles which resulted in giving meaning blurred, giving rise to different interpretation opportunities, which resulted in the establishment of forgotten the original purpose of Article 6 UUHT.

Character parate execution and sell on their own power or eigenmachtige Verkoop (the right to sale), but its application refers to the following clarity. Implementation parate execution HIR subject to Article 224, Article 256 RBG if not agreed upon itself the power to sell auction sales (eexecutoriale Verkoop) should be requested to the Chairman of the PN and Demand by reason of default or breach of contract. Therefore breach is not regulated in Article $6 \mathrm{UUHT}$, then to determine the existence of a breach of contract refers to the provisions of Article 
1243 of the Civil Code, or in accordance with the agreements stipulated in the agreement. If the reference is analogous to the provisions of Article 1178 of the Civil Code, which is categorized breach if the debtor does not repay the principal debt, or do not pay interest owed, as appropriate.

This article is conflicting provisions in relation to Article 6 of the explanation. In one sense, Article 6 itself authorize the holder to sell itself to the promise of HT if the debtor injury. However, the explanation of Article itself, emphasized the holder to sell its own HT (rechts van eigenmachtige Verkoop) if it is attached to the new agreement. Thus, one aspect under this article, the formulation implied that the power to sell itself as if it is ipso jure (by law) awarded to the holder of legislation $\mathrm{HT}$, but in the light of that article, is not ipso jure, but it should be by consensus.

According to this explanation, the right to sell the object of Encumbrance on its own power, is one manifestation of the position prioritized or preferential rights owned by the holder or holders of Mortgage First Mortgage, Mortgage holders if more than one person. Right to sell on its own power new embedded when the agreement expressly provided in the Deed of Encumbrances, namely the granting of the Elucidation of Article 6 should be based on the "promise" or "clause" arrives given the debtor or the Giver Mortgage Holder Mortgage (creditors). Promise provides confirmation if the debtor or grantor Mortgage appointment injury, the holder is entitled to sell the object Encumbrance Encumbrance through public auction without requiring further approval from lender Mortgage.
From the sale, creditors took the first repayment of creditors entitled to take repayment of the entire debt from the sale first, with the exclusion of the other creditors. If there are remaining, entitled Mortgage provider, therefore, must be handed over to him.

Concepts and systems sell on its own authority under Article 6 UUHT, similar to those outlined Article 1178 of the Civil Code, which must be affirmed as a clause in the deed of Encumbrances Encumbrance (APHT). Mortgage Law has yet to regulate the Implementation Regulations. So that based on the foregoing, it can be understood that the auction should be through a request Mortgage fiat (determination) to the Chairman of the Court authorized. This is in accordance with Article 224 HIR governing the execution parate institutions.

Without going through the execution parate institutions in accordance with Article 224 HIR it can be said the auction process carried out executions Mortgage banks as customers jammed debtors directly to institutions in the category auction is not in accordance with the legislation (other undue process the law). As is the case, when an auction execution directly Mortgage Institution conducted through auction will be a lot of resistance from the debtor. Usually through a state debate definite amount of the debt. Although through the efforts Resistance is ultimately the principal case examined by the Court, but would have violated the civil law should be. Here the law unification has not happened because of the attitude of the Supreme Court is not strict or even ambiguous in determining the auction procedure code execution Mortgage should be. The 
jurisprudence of the Supreme Court has not expressly set it up so many parties, both from banks or borrowers try doing these legal actions.

As the emphasis in understanding the intent of the Act, the following sounds cited Supreme Court of the Republic of Indonesia No. 3210 K / Pdt / 1984 dated January 30, 1986 which is under consideration verdict stated that the execution of the mortgage deed prosse headed by Justice sake of Almighty God under Article $224 \mathrm{HIR}$, has the same power with the Court decision is legally binding. However, its implementation should be through the intervention of the District Court, because of the general office referred to in Article 1211 Book of the Law of Civil Law is the Court, not the Auction Office. Therefore, the sale of auction Auction Office Bandung without the behest of Chairman of the Court, but directly at the request of the Bank (Creditor) is invalid.

Despite the above mentioned Decision to appear before the enactment of Act No. 4/1996 on Encumbrance but in understanding the law in accordance with Article 224 HIR jo. Article 1211 Book of Civil Law Act. In this case there has been no law or new regulations should change the old provisions that are worn. Therefore the auction execution Encumbrance without the intervention of the Chief Justice is not legally meet the event (other undue process of the law).

Through the intervention of the Court of fiat or more stipulation reflects the balance of interests and meet the principles of justice in case the Court has examined the adequacy of the reason of issuing the order. Besides, the debtor will receive admonition Rights (aanmaning) and could explain the light directly to the competent Court. Each party gets the right and obligation to defend its interests in a balanced manner in front of before, which is filled by the auction agency for not having proof room again.

Although in principle, an institution intended to allow the execution parate execution can be carried out immediately, but the terms and conditions "if the debtor breach" in Article 6 of Law Encumbrance make ekskekusi is certain is conditional or unconditional. The rise of a lawsuit as a result of collateral assets auctioned off by banks in addition to the psychological effects are executed, also affected because it is so lax restrictions coming into effect of the law.

\section{Legal Protection of Debtor In Perspective of Act No. 8 of 1999 on Consumer Protection (BFL) and Auction Limit Values Determination Protection Guarantee Mortgage}

Consumers are one of the perpetrators of economic activities in a State. Consumer is the individual / group of people who consume the goods or services supplied by the manufacturer. There is the consumer understanding of the experts: ${ }^{6}$

a. Philip Kotler "consumers are all individuals and households who buy or acquire goods or services for personal consumption".

b. Hornby "consumer is any user of goods and / or services available in the community, for the benefit of themselves, their families, other

6 Dhika augustyas, "Perlindungan Hukum Bagi Konsumen", https://dhiasitsme.wordpress.com/2012/04/18/perlin dungan-hukum-bagi-konsumen/ on May 10, 2015 at 14:34 pm 
people, as well as other living beings and not for sale".

Consumers as a user of the goods or services requires a clear legal protection in getting the satisfaction and the appropriateness of consuming goods or services. According to the Consumer Protection Act No. 8 of 1999, section 1, point 1 is "all efforts which ensure legal certainty to provide protection to consumers". In this regard it in any use of the product or service by consumers, consumers are entitled to legal certainty.

Consumer protection for many kinds, such as the protection of the health and safety of consumers, the right comfort, the right is well served by both producers and markets, the right to earn a decent goods or services and so forth. The number of rights under consumer protection caused by factors that the consumer is an important economic players, because without the consumer in the production of goods or services, then the economy will not run. If the products / services produced not in accordance with the demand of the consumer, then the consumer satisfaction will be minimal, causing imbalances in the economy as well as the production of goods or services.

In Article 2 of Act No. 8 / 1999 contains the principle of consumer protection where in the article states that the protection of consumers based on merit, justice, equity, security and safety of consumers, as well as legal certainty. Therefore, consumer protection, should every aspect of both the producers and the market as well as the role of government is necessary and always refers to the principles, namely: ${ }^{7}$

a. Utility Function in this case both the producers and consumers have the same position so there is no loss of each party and to obtain their rights as producers and consumers.

b. The principle of justice is a principle most often violated by one party, because it is supposed in this case businesses (manufacturers) to be fair to create a goods / services, both in the manufacturing process as well as in the pricing process. With a sense of justice, then no party feels aggrieved in this regard.

c. The principle of balance is a principle whereby a balance between the interests of consumers and producers as well as other parties such as the government so as to create a good and stable economy.

d. The principle of security and safety of consumers is a principle where any goods / services produced already qualified to be produced and approved by a legal entity authorized so that the products offered and sold to consumers suitable for consumption because of the use of the goods / services by consumers it also involves for the safety of consumers which must be borne by the manufacturer or the government in the event of an accident.

e. The principle of legal certainty is a principle that makes businesses and consumers to comply with applicable regulations and so will not violate the law that has been set. With the lack of legal certainty so consumers can also use the product / service 
with a sense of security and can be a guarantee in case something undesirable in the use of products / services.

Apart from having to refer to the principle of consumer protection carried out for various purposes. The purpose of consumer protection under article 3 of Act No. 8/1999, which is to increase awareness, ability and independence of consumers to protect themselves. In addition, the dignity of the consumer by way keep them from negative access user of goods and / or services. Another aim is to increase the empowerment of consumers in selecting, specifying, and demand their rights as consumers. Consumer protection also aims to create a consumer protection system contains elements of legal certainty and transparency of information and access to information, raise awareness of businesses about the importance of consumer protection so that the growing attitude of honest and responsible in trying,

Settingsthrough UUPK were strongly associated with legal protection for bank customers as consumers are provisions concerning the procedures for the inclusion of standard clauses. Standard clauses are any rules or the terms and conditions have been determined beforehand diperisiapkan and unilaterally by businesses set forth in a document and / or agreement that is binding and must be met by consumers.presencelegal protection for customers in the banking sector as consumers become urgent, because in fact the position of the parties is often unbalanced. The credit agreement / financing and bank account opening agreement that should be made by agreement of the parties, for reasons of efficiency replaced by an agreement that has been made by parties bargaining (bargaining position) in this case is the bank. Customers do not have any other choice but to accept or reject the agreement offered by the bank (take it or leave it). ${ }^{8}$

Inclusion clauses in the loan agreement / financing Reviewed duly bank is a partnership effort, as well as the bank's creditors and debtors both need each other in an effort to expand its business respectively. ClauseSuch a tight based on the attitude of banks to implement the principle of prudence in lending / financing. In providing protection against the debtor it is necessary regulations on credit are realized so that it can serve as a guide in lending. On the other side of the court which is a third party to resolve disputes between the bank and the debtor can assess whether the efforts made by both parties in accordance with the agreed and did not violate the provisions of law.

Objection to the standard agreement, among others because of the content and the terms have been prepared by one of the parties, does not know the content and the terms of the standard agreement and if they know do not know the reach of the legal consequences, one of the parties is economically more powerful, and there is an element "forced" to sign the agreement. ${ }^{9}$ The reasons for the creation of a standard agreement is for the sake of efficiency.

Presence circumstances, the underlying substance of BFL to provide
8 Ibid, P.10

9 Ibid, p.15 
arrangements regarding the inclusion of the provision of standard clauses, as follows: ${ }^{10}$

1. Business operators in offering goods and / or services that are held for trading are prohibited from creating or listing standard clause in every document and / or agreement if:

a. declare the transfer of responsibility of businesses;

b. stated that businesses are entitled to reject the handover to the goods bought by consumers;

c. stated that businesses are entitled to reject the handover to the money paid for the goods and / or services purchased by consumers;

d. express authorization from consumers to businesses, either directly, or indirectly to any unilateral actions relating to goods purchased by consumers in installments;

e. set regarding proof of loss of use of goods or utilization of services purchased by consumers;

f. entitles businesses to reduce the benefits of the services or reduce the wealth of consumers who becomes the object of sale and purchase of services;

g. consumer subjection to the rules stated in the form of new rules, additional, secondary and / or advanced conversion made unilaterally by businesses in the future consumers to use services purchased; h. stating that the consumer authorizes the business to loading encumbrance, lien or security interest against goods purchased by consumers in installments. Business agents are prohibited include standard clauses that location or shape is hardly visible or can not be read clearly, or the disclosure of which is difficult to understand.

3. Each standard clause that has been set by the business documents or agreements that comply with the provisions referred to in paragraph 1 and paragraph 2 shall be deemed void.

4. Business operators are required to adjust the standard clause that is contrary to this Act.

For the provision of Article 18 is very closely related and often occur in the credit agreement / financing granted by banks is the provision in paragraph (1) letter $\mathrm{g}$, namely that the bank stating the submission of consumers to regulation in the form of new rules, additional, secondary and / or further alteration made unilaterally by businesses in the future consumers utilizing the services that they purchase. The provisions concerning the standard clause is set in the $B F L$, but in reality is often still a breach that would be detrimental to the interests of customers. Things that should be considered by the bank to eliminate or at least minimize losses to clients, because it must be in the form of a standard agreement, among others, are as follows: ${ }^{11}$

a. Provide sufficient warning to clients of the existence and enactment of important clauses in the agreement. 
b. Notification shall be made before or at the time of signing the credit agreement / financing.

c. Formulated in words and sentences are clear.

d. Provides ample opportunities for the debtor to know the contents of the agreement.

In the perspective of the Consumer Protection Act (BFL) is connected to the case of the position of civil cases that I researched, the point to be underlined is related to the application of the principle of protection of consumers / debtors. SomeThe points include the principle of benefits, in this case both the creditor and debtor have the same position so there is no loss of each party and to obtain their rights as creditors and the Debtor. The principle of justice, a principle most often violated by one party, because it is supposed in this case businesses (manufacturers) to be fair to create a goods / services, both in the manufacturing process as well as in the pricing process. With a sense of justice, then no party feels aggrieved in this regard. The principle of balance, a principle whereby a balance between the interests of debtors and creditors and other parties such as the government so as to create a good and stable economy. The principle of security and safety of the Borrower is a principle where any goods / services produced already qualified to be produced and approved by a legal entity authorized so that the products offered and sold to consumers suitable for consumption because of the use of the goods / services by the Borrower it also involves for the safety of the Borrower to be borne by creditors and the government in the event of an accident. The principle of legal certainty, the principle that makes entrepreneurs or debtor may comply with applicable regulations and so will not violate the law that has been set. With the lack of legal certainty then the debtor can also use the product / service with a sense of security and can be a guarantee in case something undesirable in the use of products / services.

Difficulty in resolving the problem of bad loans due to several factors of which stems from the lack of attention to the provisions relating to the legal guarantee, particularly in the use of land as collateral for loans. Even though the land is not the only guarantee, but it should be recognized that the land still has more value when compared with other forms of collateral, this is because the land is not easily lost or damaged, and the price tends to increase, especially land in urban areas. ${ }^{12}$

Given the economic value is high enough, then the use of land as loan collateral in banking circles these days occupy priorities / precedence over other collateral objects.

In conjunction with the lender to sell on its own power through a public auction object security rights if the debtor in default and take repayment of its receivables from the sale proceeds, should continue to consider that the object of the security rights that are owned by the Debtor as a provider of security rights so that at the time of sale of objects of mortgage in the auction

12 Budi Harsono, 1998, "Upaya Badan Pertanahan Nasional Dalam Mempercepat Penyelesaian Kredit Macet Perbankan", Kumpulan Makalah dan Hasil Diskusi Panel I Sampai IV Pengurusan Piutang dan Lelang Negara, Dep. Keu,. RI. BUPLN), Jakarta, P. 400 
remain based on the respect for the property of others.

The understanding that the donor Encumbrance is always interested in the object of the security rights is essential in nature, because in case of sale of mortgage object must always be hope that the object of mortgage borrowers who can provide high sales results.

The concept of collateral through public auction itself is actually aimed in hopes obtained the highest price for the object of mortgage. So when the auction concept has implications for the opposite field, then comes a lot of cases related to the auction. In accordance with the principle of decency and good faith, the bank does not determine your own selling price of the goods of the collateral in the settlement of non-performing loans of debtors. Supposedly appraisals object of encumbrance first performed by an appraiser (appraisal company) that is independent and has a good reputation.

Lawsuit Case Debtor itself the essence of the problem is the sales price of the object of mortgage are considered unnatural. Evidence can be submitted by the plaintiff is that the bank had acted against the law or contrary to decency or contrary to justice or contrary to the principle of good faith towards the sale price of the object of mortgage are considered unnatural. Thus it is reasonable that if the principle of decency and good faith and the principle of respect for the property of others made reference Creditor / bank in determining the price of the goods of the collateral in the settlement of non-performing loans customers / debtors.

Aspects of the importance of the Bank consider the fairness of the sale value of the object of collateral is also evident in the case of the case in appeals court (Court of Appeal), which was unanimously (unanimously) has decided that in exercising its authority to sell the collateral was, the defendant in this case the bank-bound to achieve the actual price (true value) of the property. Judge Salmon LJ pointed out that: ${ }^{13}$

"accordingly conclude, both on principal and auhority, that mortgagee in exercising his power of sale does owe a duty to take reasonable precautions to Obtain the true market value of the mortgaged Whether the has fallen short of that duty, $k$ the facts must be looked at broadly, and he will not be adjudged to be in default UNLESS he is plainly on the wrong side of the line.

\section{CONCLUSION}

Opportunities for the emergence of resistance debtor due to the device legislation in this regard UUHT turned out contained some weaknesses, namely, UUHT not regulate limits the definition of default, the inconsistency between Article 6 (the right to sell on its own power) and the elucidation of Article 6 (right to sell on power alone but on the basis of agreement / agreement between the creditor and the debtor). This resulted in the emergence of a different interpretation opportunities. Land is a credit guarantee with a high economic value, and a lower priority than other collateral objects. So considering that the object of the security rights that belong to the debtor, to the principles of propriety, good faith and respect for the property of others is very critical to the creditor. The concept of auction aims to obtain the

13 Adrian Sutedi, 2012, Hukum Hak Tanggungan, Sinar Grafika, Jakarta, P. 142 
highest price, but in practice occur counterproductive because the lender / bank determines unilaterally limit value auction object $\mathrm{HT}$, so the selling price of the auction becomes very unnatural and there is the potential for engineered auction by "mafia auction" that has been the secret Generally, this is the main trigger factor for the emergence of resistance of the debtor in this aspect of the debtor clearly disadvantaged. The actual price (true value) can be obtained with the engagement of an independent appraiser / assessor independent with good reputation in the determination of the limit value auction. so the auction sale price being very reasonable and there is potential auction engineered by "mafia auction" that has become public knowledge, this is the main trigger factor for the emergence of resistance of the debtor in this aspect of the debtor clearly disadvantaged. The actual price (true value) can be obtained with the engagement of an independent appraiser / assessor independent with good reputation in the determination of the limit value auction. so the auction sale price being very reasonable and there is potential auction engineered by "mafia auction" that has become public knowledge, this is the main trigger factor for the emergence of resistance of the debtor in this aspect of the debtor clearly disadvantaged. The actual price (true value) can be obtained with the engagement of an independent appraiser / assessor independent with good reputation in the determination of the limit value auction.

\section{BIBLIOGRAPHY}

Adrian Sutedi, 2012, Hukum Hak Tanggungan, Sinar Grafika, Jakarta, P. 142

Budi Harsono, 1998, "Upaya Badan Pertanahan Nasional Dalam Mempercepat Penyelesaian Kredit Macet Perbankan", Kumpulan Makalah dan Hasil Diskusi Panel I Sampai IV Pengurusan Piutang dan Lelang Negara, Dep. Keu,. RI. BUPLM), Jakarta, P. 400
Dhika augustyas, "Perlindungan Hukum Bagi Konsumen", https://dhiasitsme.wordpress.com/2012/04/18/perlindungan-hukum-bagi-konsumen/ on May 10, 2015 at 14:34 pm

Poesoko Herowati 2007, Parate Executie Obyek Hak Tanggungan (Inkonsistensi, Konflik Norma dan Kesesatan Penalaran dalam UUHT), LaksBang Pressindo, Yogyakarta, P. 249 